\title{
ЕТНОКУЛЬТУРНА СПАДЩИНА РЕГІОНІВ УКРАЇНИ В ПИТАННІ АДМІНІСТРАТИВНО-ТЕРИТОРІАЛЬНОГО ПОДІЛУ
}

\section{Роговенко О. В.}

\begin{abstract}
У грудні 2019 року президентом України В. Зеленським було представлено Проєкт Закону України «Про внесення змін до Конституції України (щодо децентралізації влади)» № 2598 від 13.12.2019 р. (далі Законопроєкт), що передбачає трирівневу систему адміністративно-територіального устрою - громада (базовий рівень), округ (субрегіональний рівень), області (області та Автономна Республіка Крим) [1]. 3 огляду на те, що Законопроєкт має статус невідкладного та отримав безпрецедентну підтримку Комітету Верховної Ради України з питань правової політики, широкої дискусії з питання обговорення змісту законопроєкту не передбачається. А втім, на нашу думку, є необхідність обговорення Законопроєкту, врахування позицій експертів, зокрема з позиціі етнокультурного потенціалу регіонів України, розвитку національної ідентичності України в питанні адміністративно-територіального поділу.
\end{abstract}

Україна як ніколи повинна прагнути збереження історичної культурної спадщини та, на нашу думку, після широкої дискусії та консультацій із провідними істориками-експертами, визначити етнокультурні регіони, захист та розвиток яких має бути одним зі стратегічних завдань української держави в ім'я іï майбутніх поколінь. Взявши до уваги вищенаведене, вважаємо, що варто повернутись до обговорення назви найбільших адміністративних утворень, пропонованих у проєкті до Конституції України, та передбачити в системі адміністративно-територіального устрою поряд або замість області регіони. До слова, назви «громада» (базовий рівень) та «округ» (субрегіональний рівень) теж залишаються дискусійними. Зауважимо, що поспіх у цьому питанні не є бажаним, а широкі консультації їх громадою спонукатиме суспільство до виважених рішень mа авторитету адміністративно-територіальної реформи.

На наше глибоке переконання, успіх реформи залежить від інтегрального поєднання української спадщини, кращих етнорегіональних традицій та сучасного локального менеджменту. Переважна більшість країн світу вважає засадничими питання історичного походження, етнічно-культурних цінностей спільнот, що є основою державності та розвитку, не дозволяє «розмити» національну ідентичність.

(с) Роговенко О. В., 2020
Відповідно до пояснювальної записки до Законопроєкту метою запропонованих Законопроєктом змін є зміцнення конституційно-правових засад місцевого самоврядування, підвищення ефективності системи місцевого самоврядування, здатної забезпечити оптимальні умови для реалізації прав і свобод людини на рівні громади, округу та області, сприяння подальшому розвитку форм безпосередньої демократії та децентралізації влади, визначення раціональної просторової основи організації влади для забезпечення децентралізаціі, доступності та якості надання адміністративних послуг, посилення спроможності та відповідальності громад за свій розвиток, створення передумов стійкого розвитку територій». Узявши до уваги вищенаведене, пропонуємо доповнити мету реформи положенням щодо збереження історичної культурної спадщини шляхом розвитку етнокультурних регіонів України.

Ключові слова: децентралізація, реформа, адміністративно-територіальний поділ, етнокультурна спадщина, регіон.

В декабре 2019 года Президентом Украины B. Зеленским был представлен проект закона Украины «О внесении изменений в Конституцию Украины» (относительно децентрализации власти) № 2598 om 13.12.2019 г. (Далее - Законопроект), предусматривающий трехуровневую систему административно-территориального устройства - община (базовый уровень), округ (субрегиональный уровень), области (области и Автономная Республика Крым) [1]. Учитывая то, что Законопроект имеет статус неотложного и получил беспрецедентную поддержку Комитета Верховной Рады Украины по вопросам правовой политики, широкой дискуссии по вопросу обсуждения содержания законопроекта не предвидится. Тем не менее, по нашему мнению, существует необходимость обсуждения законопроекта, учет позиций экспертов, в частности, с позиции этнокультурного потенциала регионов Украины, развития национальной идентичности Украины в вопросе административно-территориального деления.

Украина как никогда должна стремиться к сохранению исторического и культурного наследия и, по нашему мнению, после широкой дискуссии и консультаций с ведущими историками-экспертами, определить этнокультурные регионы, защита и развитие 
которых должна быть одной из стратегических задач украинского государства во имя ее будущих поколений. Принимая во внимание вышеизложенное, считаем, что следует вернуться к обсуждению названия крупнейших административных образований, предлагаемых в проекте Конституции Украины и предусмотреть в системе административно-территориального устройства рядом или вместо области - регионы. К слову, названия «община» (базовый уровень) и «округ» (субрегиональный уровень) тоже остаются дискуссионными. Заметим, что спешка в данном вопросе не является желательной, а широкие консультации их общественностью будут побуждать общество к правильным решениям и авторитету административно-территориальной реформы.

По нашему глубокому убеждению, успех реформы зависит от интегрального сочетание украинского наследия, лучших этнорегиональных традиций и современного локального менеджмента. Подавляющее большинство стран мира считает основополагающими вопрос исторического происхождения, этнически-культурных ценностей сообществ, является стволом государственности и развития, не позволяет «размыть» национальную идентичность.

Согласно пояснительной записке к Законопроекту, целью предложенных законопроектом изменений является укрепление конституционно-правовых основ местного самоуправления, повышение эффективности системы местного самоуправления, способной обеспечить оптимальные условия для реализации прав и свобод человека на уровне общины, округа и области, содействие дальнейшему развитию форм непосредственной демократии и децентрализации власти, определения рациональной пространственной основы организации власти для обеспечения децентрализации, доступности и качества предоставления административных услуг, усиления способности и ответственности общин за свое развитие, создание предпосылок устойчивого развития территорий». Принимая во внимание вышесказанное, предлагаем дополнить цель реформы положением о сохранении исторического и культурного наследия путем развития этнокультурных регионов Украины.

Ключевые слова: децентрализация, реформа, административно-территориальное деление, этнокультурное наследие, регион.

Rogovenko 0. V. Ethno-cultural heritage of the regions of Ukraine in the administrative-territorial division

In December 2019, the President of Ukraine. Zelensky was presented the Draft law of Ukraine "On amendments to the Constitution of Ukraine (regarding decentralization of power) No. 2598 from 13.12.2019 G. (hereinafter the law), which provides for three-tier system of admin- istrative-territorial unit - the community (basic level), district (subregional level), region (oblast and the Autonomous Republic of Crimea) [1]. Given the fact that the Bill has the status prompt and received unprecedented support of the Verkhovna Rada Committee on legal policy of a broad discussion on the question of discussing the content of the bill is not expected. However, in our opinion there is a need for discussion of the Bill, taking into account the positions of experts, in particular, from the perspective of ethno-cultural potential of regions of Ukraine, the development of national identity of Ukraine in administrative-territorial division.

Ukraine should seek to preserve the historical and cultural heritage and, in our opinion, after extensive discussions and consultations with leading historians and experts to determine the ethno-cultural regions, protection and development of which should be one of the strategic tasks of the Ukrainian state in the name of future generations. Taking the above into consideration, we believe that we need to revisit the names of the major administrative units proposed in the draft of the Constitution of Ukraine and to provide in the administrative-territorial device along with or instead of region - regions. By the way, the name "community" (basic level) and district (sub-regional level) also remain controversial. Note that haste in this matter is not desirable, and extensive consultations IX community to encourage society to a balanced decision and authority of the administrativeterritorial reform.

In our opinion, the success of the reform depends on the integral combination of Ukrainian heritage, the best ethnic and regional traditions and modern local management. The vast majority of the world considers the fundamental question of the historical origin of ethnic-cultural values of communities, which is the trunk of the statehood and development and prevents blur national identity. According to the explanatory note to the Bill, the proposed amendments to the Bill are to strengthen the constitutional and legal foundations of local self-government, to increase the effectiveness of the local self-government system, which is able to provide optimal conditions for the realization of human rights and freedoms at the community, county and oblast levels, and to promote the further development of democratic forms of democracy. Decentralization of power, defining a rational spatial framework for organizing power to ensure decentralization, accessibility and quality adannya administrative services, increased capacity and responsibility for their community development, creating prerequisites of sustainable development areas". In view of the above, we propose to supplement the reform objective with the provisions on the preservation of the historical cultural heritage through the development of ethno-cultural regions of Ukraine.

Key words: decentralization, reform, administrative-territorial division, ethno-cultural heritage, region. 
Постановка проблеми та іï актуальність. У грудні 2019 року президентом України В. Зеленським було представлено Проєкт Закону України «Про внесення змін до Конституції України» (щодо децентралізації влади) № 2598 від 13.12.2019 р. (далі - Законопроєкт), що передбачає трирівневу системуадміністративно-територіальногоустроюгромада (базовий рівень), округ (субрегіональний рівень), області (області та Автономна Республіка Крим) [1]. 3 огляду на те, що Законопроєкт має статус невідкладного та отримав безпрецедентну підтримку Комітету Верховної Ради України з питань правової політики, широкої дискусії з питання обговорення змісту законопроєкту не передбачається. А втім, на нашу думку, $\epsilon$ необхідність обговорення Законопроєкту, врахування позицій експертів, зокрема, з позиції етнокультурного потенціалу регіонів України, розвитку національної ідентичності України в питанні адміністративно-територіального поділу.

Аналіз останніх досліджень i публікацій. Проблемі ефективного адміністративно-територіального устрою України в загальному та історико-правовому контексті присвячували свої праці таки автори, як О.М. Бабич, О.І. Бойко, К.М. Вітман, Я.В. Верменич, Ю.І. Ганущак, Ю.О. Карпінський, І.О. Кресіна, А.А. Коваленко, О.Г. Кучабський, В.Г. Куйбіда, Ю.П. Мателешко, С. Макарчук, О.Я. Матвіїшин, В.А. Негода, В.П. Павленко, Є.В. Перегуда, М.О. Пухтинський, О.В. Скрипнюк, О.М. Стойко, А.Ф. Ткачук, В.І. Шабельников, В.А. Явір, В.А. Яцюк, та інші автори. Серед зарубіжних авторів під час підготовки цієї статті особливо цінними були матеріали литовського автора Альгерда Астраускаса. Незважаючи на широкий контекст дослідження, питання розвитку адміністративно-територіальних одиниць, 3 огляду на зміст Законопроєкту, на наш погляд, потребує широкої дискусії.

Метою статті $\epsilon$ здійснення аналізу ефективності адміністративно-територіального поділу України, визначеного у Проєкті Закону України «Про внесення змін до Конституції України (щодо децентралізації влади)» № 2598 від 13.12.2019 р. щодо національної ідентичності, розвитку етнокультурних регіонів України.

Виклад основного матеріалу. Автор поданої статті висуває гіпотезу, що одним із важливих критеріїв, що визначають ефективність та перспективу адміністративно-територіального поділу в Україні, її національну ідентичність $€$ етнокультурний потенціал.

Адміністративно-територіальний поділ у різних країнах світу передбачає диференційований підхід щодо типів та рівнів адміністративних одиниць. Зазвичай адміністративні одиниці поділяються від першого (найбільшого) до четвертого (найменшого) рівня адміністративного поділу. Так, наприклад, Алжир має 48 провінцій (найбільший адміністративний рівень), 553 округи, 1541 комун, які складаються із сел (найнижчий четвертий рівень адміністративного поділу) [2]. Класичним прикладом чотирирівневого адміністративного поділу $\epsilon$ Великобританія, яка складається із 4 історичних провінцій (Англія, Північна Ірландія, Уельс, Шотландія), кожна з яких складається із регіонів, графств, міст-графств, округів; наприклад, Англія складається з 9 регіонів, які містять 6 графств-метрополій, 28 графств, Великий Лондон, що, зі свого боку, поділяються на 36 метрополітенських районів, 201 районів графств, 33 адміністративних округи). Більшість країн обмежуються дво- або трирівневим поділом на адміністративні одиниці. Наприклад, Данія поділяється на 5 областей, що, зі свого боку, поділяються на 98 комун. Адміністративно-територіальний поділ у різних країнах світу може мати такі назви, як штат, земля, регіон, провінція, губернія, область, волость, сектор, округ, департамент, муніципалітет, район, квартал, комуна, місто, село, селище, тощо.

Назви адміністративно-територіальних одиниць залежать від культурно-історичної спадщини конкретної країни, особливостей розвитку їі території. Україна мала різні назви адміністративно-територіальних одиниць в різні історичні періоди свого функціонування.

Так, одиницями адміністративно-територіальних утворень Київської Русі X-XI ст. були «земля», «волость», «град», «село», «верв», «погост» [3].

У період із XVIII - до початку XX століття під час перебування українських земель у Російський імперії адміністративно-територіальний поділ охоплював назви «губернія», «намісництво» (наприклад, із 1780 по 1796 рік функціонувало Харківське намісництво), що нерідко реорганізовувалось, змінювало кордони та адміністративний устрій (наприклад, у 1765-780 роки існувала Слобідська-Українська губернія, в період із 1780 до 1796 рік - Харківське намісництво, з 1835 року була утворена Харківська губернія, що проіснувала до 1925 року. Під час зміни влади змінювались кордони адміністративно-територіальних одиниць.

6 березня 1918 року Центральна Рада прийняла Закон «Про адміністративно-територіальний поділ України», відповідно до якого територія УНР поді- 
лялася на землі, волості та громади [4, с. 22]. Мало бути створено 32 землі (ідея Грушевського полягала в тому, щоби населення кожної землі становило приблизно 1 мільйон осіб [5]. Уже після прийняття закону було проголошено дві нові землі - Підляшшя та Дреговицьку землю, на які претендувала також Білоруська Народна Республіка. 1919 року окремою адміністративною одиницею повинна була стати територія Західноукраїнської Народної Республіки. Акт Злуки 22 січня

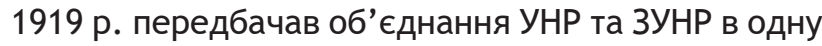
державу, з автономним статусом ЗУНР (під назвою Західна область УНР, ЗОУНР). Відповідно до закону, було три рівні адміністративного поділу: земля (найвищий рівень), волость (середній) та громада (нижчий). Волості входили до земель, але були самоуправними одиницями. Представницьким органом влади було волосне земство. Більшовики на контрольованих ними територіях скликали волосні з'їзди рад селянських і батрацьких депутатів, які, на противагу волосним земствам, створювали волосні ради депутатів та волосні виконкоми, а також волосні комітети бідноти. Волості залишились після утворення УСРР як адміністративно-територіальні одиниці, якими керували волосні з'їзди рад та обрані ними волосні виконкоми. Після проведення адміністративної реформи УСРР (7 березня 1923 року) волості замінили на 706 районів (починаючи з 1 січня 1924-го - 700).

Утім, через умови війни об'єднання мало декларативний характер, а невдовзі територію ЗУНР окупувала Польща. Однак проєкт адміністративного поділу не було завершено. Спершу його скасував гетьман Скоропадський, що перейняв владу в УНР 29 квітня 1918 року й невдовзі повернув поділ на губернії та повіти часів Російської імпеpiї. Українська держава поділялася на 9 губерній і 2 округи [6, с. 232]. Пізніше реалізації реформи перешкодили обставини війни й поразка УНР.

Таким чином, адміністративно-територіальний поділ територій в Україні залежав від історичного періоду, політики держав, до складу яких уходила Україна. Історично найтиповішою, найбільшою адміністративно-територіальною одиницею України була «земля», але, як зазначає Ю.П. Мателешко, «земля» - це передусім державне утворення [3]. На нашу думку, суспільне сприйняття слова «земля» $\epsilon$ придатним для федеративного устрою України, що наразі викликає гостру дискусію. Нині Україна - унітарна держава, яка прагне побудувати ефективну систему територіальної організації влади в Україні, що і в сучасному розу- мінні, i надалі прагне уникати сепаратистських настроїв та має бути уважною до понятійного інструментарію адміністративно-територіального устрою держави. Безумовно, зазначене не применшує ролі та значення історичної спадщини, ретельне дослідження якої $\epsilon$ важливим завданням сучасної історичної науки.

Більшого значення, на нашу думку, набувають етнічні характеристики української спільноти, які мають бути відображені в адміністративно-територіальному поділі. Кожному регіону України притаманні свої культурні, етнічні особливості - від оздоблення житла, одягу (вишиванок тощо) до пісень та приказок. Ці питання $\epsilon$ національним скарбом та нерідко характеризують належність до конкретної території.

Наприклад, можна взяти уважний, державницький підхід Литви. Так, Литва $\epsilon$ досить однорідною за своїм етнічним складом: $85 \%$ населення - литовці (за національністю). Однак литовська нація еволюціонувала з певних племен та етнічних утворень, які мали специфічні культурні особливості: мову та пісні, традиції та звичаї, одяг, архітектуру, рецепти, традиційний спосіб життя тощо. Все це поважають у Литві, яка намагається зберегти його культурні особливості для майбутніх поколінь. Тому з метою сприяння розвитку цієї історичної культурної спадщини Литва поділяється на п'ять етнокультурних регіонів із 1999 року: райони нагір'я (Авкштайтія), Дайнава (Дзюкія), Малої Литви (Мажоджі Летюва), Самогітії (Жемайтія) та Судовиї (Сувалкія). Правові умови цих регіонів були створені в цих регіонах для функціонування регіональних рад із метою захисту етнічної культури, діяльності, яка спрямовується, координується та фінансується Радою з питань захисту етнічної культури при сеймі Литовської Республіки [7].

Етнокультурні регіони стають складовою ідентичності населення України-Русі, починаючи з XI століття. Про перші з них згадується в давньоукраїнських літописах, виокремлюючи із загальної спільності Рустію, Галицьку землю, Надбужжя, Холмщину (Забужжя), Підляшшя (Підлісся), Перемишлянщину, Надросся, Переяславщіну, Київщину, Надпоріжжя, Підкарпатську Русь. Згодом, у XII-XIII століттях історичні документи фіксують і такі утворення - Червону Русь, Покуття, Поділля, Волинь, Чернігівщину, Полісся, а в пізніші часи, з XIV до XVI ст. - Запоріжжя, Басарабія, Північне Причорномор' $\epsilon$, Берестейщину, Любарці, а в XVII-XVIII ст. - Донщину, Гетьманщину, Задунайську Січ, Слобожанщину, Новоросію, Таврію, 
Кубанщину. Однозначний перелік регіонів визначити важко, але більшість історичних областей $\epsilon$ загальновизнаними [8].

Як зазначає О.Ю. Косміна, терміном «етнографічний регіон» означають частину території розселення етносу, що вирізняється 3-поміж сусідніх частин притаманним їй комплексом ознак (явищ) матеріальної та духовної культури цього етносу [9, с. 63-64]. Як позначає автор, «за матеріалами найбільших комплексних етнографічних досліджень українських земель, що були здійснені наприкінці XIX - початку XX століття, в межах сучасних державних кордонів України можна виділити більше XXIV етнографічних регіонів» [10] (деякі з них складаються із субрегіонів) та об'єднує їх у 4 макрорегіони: Полісся, Лісостеп, Степ, Карпати.

Полісся. Цей макрорегіон охоплює північну смугу українських теренів. До його складу входять 3 правобережних (відносно Дніпра) і 2 лівобережні поліські землі. Традиційна культура населення правобережних польських земель (Волинського, Житомирського та Київського Полісся) відрізняється від традиційної культури населення поліських лівобережних земель (Чернігівського та Новгород-Сіверського Полісся).

Лicocmen. Особливості цього мікрорегіону зумовлені його сприятливими природними умовами та географічним положенням, яке робило його відкритим для контактів із різними цивілізаціями. Центральний лісостеповий регіон Середнє Подніпров'я був осередком формування нації української. На Лісостеповому правобережжі розташовані Волинь, Галичина, Опілля, Поділля та більшість Середнього Подніпров'я. Середнє Подніпров'я може розглядатись як перехідна зона до сусідньої Полтавщини, що разом із Слобідською Україною належить до лісостепового лівобережжя.

Cmen. Цей макрорегіон утворився пізніше за інших. Він увійшов до зони розселення українців унаслідок колонізації, що набула масового характеру у XIV ст. До складу цього макрорегіону входять: Буджак, Одещина, Нижнє Подніпров'я, Таврія, Приазов'я, Крим.

Kapnamu. До цього макрорегіону входять такі регіони: Лемківщина, Бойківщина, Гуцульщина, Покуття, Буковина, Закарпатська Україна» [9, с. 63-64].

Висновки. Україна як ніколи повинна прагнути збереження історичної культурної спадщини та, на нашу думку, після широкої дискусії та консультацій із провідними істориками-експертами - визначити етнокультурні регіони, захист та розвиток яких має бути одним зі стратегічних завдань української держави в ім'я іiі майбутніх поколінь. Узявши до уваги вищенаведене, вважаємо, що варто повернутись до обговорення назви найбільших адміністративних утворень, пропонованих у проєкті до Конституції України та передбачити в системі адміністративно-територіального устрою поряд або замість області - регіони. До слова, назви «громада» (базовий рівень) та «округ» (субрегіональний рівень) теж залишаються дискусійними. Зауважимо, що поспіх у цьому питанні не $\epsilon$ бажаним, а широкі консультації їх громадою спонукатиме суспільство до виважених рішень та авторитету адміністративно-територіальної реформи.

На наше глибоке переконання, успіх реформи залежить від інтегрального поєднання української спадщини, кращих етнорегіональних традицій та сучасного локального менеджменту. Переважна більшість країн світу вважає засадничими питання історичного походження, етнічно-культурних цінностей спільнот, що є основою державності та розвитку, не дозволяє «розмити» національну ідентичність.

Відповідно до пояснювальної записки до Законопроєкту метою запропонованих Законопроєктом змін $€$ зміцнення конституційно-правових засад місцевого самоврядування, підвищення ефективності системи місцевого самоврядування, здатної забезпечити оптимальні умови для реалізації прав і свобод людини на рівні громади, округу та області, сприяння подальшому розвитку форм безпосередньої демократії та децентралізації влади, визначення раціональної просторової основи організації влади для забезпечення децентралізації, доступності та якості надання адміністративних послуг, посилення спроможності та відповідальності громад за свій розвиток, створення передумов стійкого розвитку територій». [11]. Узявши до уваги вищенаведене, пропонуємо доповнити мету реформи положенням щодо збереження історичної культурної спадщини шляхом розвитку етнокультурних регіонів України.

\section{Література}

1. Про внесення змін до Конституції України (щодо децентралізації влади) : Проєкт Закону України від 13.12.2019 р. № 2598 Верховна Рада України. URL: http://w1.c1.rada.gov.ua/pls/zweb2/ webproc4_1?pf3511=67644 (дата звернення: 30.12.2019).

2. Таблица административных единиц по странам URL: https://ru.wikipedia.org/wiki/ (дата звернення: 15.12.2019). 
3. Мателешко Ю.П. Адміністративно-територіальні одиниці Київської Русі X-XI ст. : проблеми термінології (історіографія питання). Науковий вісник Ужгородського університету, серія «Історія». Вип. 1(30). 2013. С. 153-159.

4. Шабельников В.І. Реформування адміністративно-територіального устрою України в 1917-1940. Монографія. Донецьк : Вид-во Донецького національного ун-ту, 2006. С. 22.

5. Губань Р.І. Історія становлення сучасного адміністративно-територіального устрою України. Юридичний журнал. 2009. № 3. URL: https: / / web.archive.org/web/20140819024207/ ht tp: / / www.justinian.com.ua/article. php?id=3159 (дата звернення: 16.12.2019).

6. Бойко О.І. Територія, кордони і адміністративно-територіальній поділ Української Держави гетьмана П. Скоропадського (1918). Регіональна історія України. Збірник наукових статей. 2009. Випуск 3.

7. Algirdas Astrauskas Regionalisation in Lithuania: an ongoing debate on regional reforms URL: \#RoR2017 https://aer.eu/regionalisation-lithuaniaongoing-debate-regional-reforms-ror2017/ (дата звернення: 30.12.2019).
8. Верменич Я.В. Земля, як термін. Енциклопедія історії України : у $10 \mathrm{~m}$. / редкол.: В.А. Смолій (голова) та ін. ; Інститут історії України НАН України. Київ, Наук. думка, 2005. Т. 3 : Е-Й. 672 с.

9. Косміна О.Ю. Етнографічні регіони України. Енциклопедія історії України : у $10 \mathrm{~m}$. / редкол.: В.А. Смолій (голова) та ін. ; Інститут історії України НАН України. Київ, Наук. думка, 2005. Т. 3 : E - Й. 672 c.

10. Історико-етнографічні райони України : навчальний посібник / Макарчук С.В. Львів : ЛНУ імені Івана Франка, 2012. 352 с.

11. Пояснювальна Записка до Проєкту Закону України від 13.12.2019 р. № 2598 Про внесення змін до Конституції України (щодо децентралізації влади). Верховна Рада України. URL: http://w1.c1. rada.gov.ua/pls/zweb2/webproc4_1?pf3511=67644 (дата звернення: 30.12.2019).

Роговенко О. В., кандидат юридичних наук, доцент, доцент кафедри адміністративного та інформаційного права Сумського національного аграрного університету 